\title{
Climate variability since last glacial maximum based on distribution of foraminifera in North Papua Waters, Pacific Ocean
}

\author{
Adrianus Damanik ${ }^{1,}{ }^{*}$, Khoiril Anwar Maryunani ${ }^{1}$, Septriono Hari Nugroho ${ }^{2}$, Purna Sulastya Putra ${ }^{2}$ \\ ${ }^{1}$ Geological Engineering, Faculty of Earth Sciences and Technology, Institut Teknologi Bandung, Bandung, Indonesia \\ ${ }^{2}$ Research Center for Geotechnology, Indonesian Institute of Sciences, Bandung, Indonesia
}

\begin{abstract}
ARTICLE INFO
ABSTRACT

Article history:

Submitted 31 May 2020

Revised 23 August 2020

Accepted 28 October 2020

Published online 31 December 2020

Keywords:

foraminifera distribution

Pacific Ocean

paleoceanography

paleoclimate

Papua Waters

Foraminifera distribution is one of the proxies used to reconstruct climatic conditions and paleoceanography. Specific species or groups of foraminifera can be associated with certain oceanographic parameters. As one of the entrances of Indonesia Through Flow (ITF), North Papua Waters has the role of channeling water masses from the Pacific Ocean to the Indonesian Waters. It is also influenced by global thermohaline circulation and ENSO. In this study, observations were made of changes in the distribution of foraminifera to reconstruct paleoclimate and paleoceanographic conditions in the North Papua Waters and their relation to global climate conditions. The analysis was performed on $246 \mathrm{~cm}$ core sediments with eight $\mathrm{cm}$ foraminifera observation intervals at sample depths $246-126 \mathrm{~cm}$ and four $\mathrm{cm}$ at sample depths of $126-0 \mathrm{~cm}$. Pulleniatina spp., Neogloboquadrina spp., and Globorotalia spp., are used for radiocarbon dating. Planktonic abundant species of foraminifera are Pulleniatina obliqueloculata, Neogloboquadrina dutertrei, Globorotalia menardii, Globigerinoides ruber, Globigerinoides trilobus, and the benthonic are Melonis pompilideus, Pullenia bulloides, Oolina sp., Planulina bradyii, Oridorsalis umbonatus, Cibicides subhaidingerii, Eggrela bradyii, Planulina wuelestroffi, and Quinqueloculina spp.,. Division according to cluster analysis can show the difference between Holocene and Pleistocene, which is then more detailed divided into 17 clusters. Based on biozonation there are some events that can be observed: climate variability since Late Pleistocene, record Pleistocene-Holocene boundary based on the significant variability of foraminifera distribution, and records some of the global climate events such as Last Glacial Maximum ( 19-17 kyr), Younger Dryas ( 11-9 kyr), and 8,2K event.
\end{abstract}

(C2020 Indonesian Institute of Sciences (LIPI).

\section{Introduction}

Foraminifera is known as a proxy of paleoclimate changes due to the species preference of specific environmental conditions, even though there is some foraminifera living in a wide range of conditions (Saraswat, 2015). Groups of species that inhabit a similar environment and have specific ecological requirements can be interpreted as similar species assemblage (Saraswat, 2015). These species assemblages are often identified with cluster analysis that shows specific and limited environment parameters such as organic flux, dissolved oxygen, grain-size, water depth (Lutze and Coulbourn, 1984; Kirci-Elmas, 2013; Saraswat, 2015).

\footnotetext{
* Corresponding Author

Adrianus Damanik adrianusdamanik@gmail.com
}

Therefore, the temporal variation in species assemblages is applied to interpret the variation of environmental conditions and is one of the most wide foraminifera proxies that are used to infer variations in paleoclimate.

Marine sediment studies show significant changes in specific foraminifera abundance as the changing of a specific environmental parameter, such as sea surface temperature, oxygen content, bottom water current, thermocline depth, bathymetry, and others (Boltovskoy and Wright, 1976; Bé and Hutson, 1977; Naidu, 1993; Fraile et al., 2008; Maryunani, 2009; Gustiantini et al., 2015; Saraswat, 2015; Ardi et al., 2019).

North Papua Waters, Pacific Ocean, is chosen as the location for the Nusa Mangala 2018 Expedition because situated in a strategic position as one of the entrances of ITF (Indonesian Through Flow), that carries warm water masses to the Indian Ocean through Indonesia and as part 
of the global thermohaline circulation (Hasanuddin, 1998). North Papua Waters is also affected by ENSO (NOAA, 2020; Ilahude and Nontji, 1999; Gordon, 2005; Sprintall et al., 2014), which is a recurring climate pattern involving the circulation of water and temperature changes in the Pacific Ocean.

The closest and most recent study around our research location is from the Halmahera Sea. Gustiantini et al. (2015) suggested that changes in the foraminifera distribution can be used to identify changes in global climatic conditions. Here we present the distribution of foraminifera from North Papua Waters, Pacific Ocean to reconstruct paleoclimate and paleoceanography variability since the Late Pleistocene.

\section{Materials and Methods}

Marine sediment, from core OS-07 $\left(01^{\circ} 17^{\prime} 41^{\prime \prime} \mathrm{N}\right.$ and $132^{\circ} 36^{\prime} 51^{\prime \prime E}$ ), was obtained during Nusa Mangala Expedition 2018 from North Papua Waters, Pacific Ocean (Figure 1). The sample was acquired by using gravity corer installed onboard Research Vessel Baruna Jaya VIII of LIPI. The sample was retrieved from $4327 \mathrm{~m}$ water depth with a core length of $246 \mathrm{~cm}$ and subsampled at every $1 \mathrm{~cm}$ interval (Nugroho and Damanik, 2018).

Geochronology for core OS-07 is constrained by two samples, in the middle $(125-126 \mathrm{~cm}$ depth) and the bottom (245-246 cm depth) of sediment core, analyzed using Accelerator Mass Spectrometry (AMS) ${ }^{14} \mathrm{C}$ at Beta Analytic Inc. Miami, Florida. AMS was conducted using three species of foraminifera, prepared at the Laboratory of Sedimentology, Geotechnology Research Center, LIPI (Indonesian Institute of Sciences), are abundant: Pulleniatina spp., Neogloboquadrina spp., and Globorotalia spp., to fulfill the required sample quantity for AMS tool (4 mg). The results were calibrated with High Probability Density Range (HPD) Method (Ramsey, 2009) using MARINE13 calibration dataset (Reimer et al., 2013) that is part of the program INTCAL 2013 by Beta Analytic Inc.
Foraminifera analysis was conducted on $\pm 10 \mathrm{~g}$ of sediment, pre-treatment was done with swirling methods considering the samples consist of unconsolidated sediment. The sample was then sieved witsh a mesh size of $170 \mu \mathrm{m}$ and $149 \mu \mathrm{m}$. The samples were filtered with water and dried in an oven at $60^{\circ} \mathrm{C}$ for around three hours. Foraminifera determination was carried out based on the following references: Barker (1960); Blow (1969); Bolli etal. (1985); Adisaputra et al. (2010). Quantitative determination was done on one part of the split with 300 individual observations of foraminifera. The number of the specimen can represent $95 \%$ of all foraminifera occurrences in a sample (Dennison and Hay, 1967). Determination with another part of the split was done to find the indeterminate species adding to the normalized quantitative determination. Normalization of the quantitative determination is done by the number of splitting and the weight of the sediment to $10 \mathrm{~g}$.

Ecological changes are identified by constrained clustering analysis, single linkage method, and Euclidean similarity index. The clustering results are displayed in the dendrogram diagram, which shows the degree of similarity between taxa is present in each sample. Indicator species (IndVal) analysis were calculated to reflect how important taxon is in representing the ecological conditions for each cluster following Dufrene and Legendre (1997).

Biofacies analysis (foraminifera associations) was done to obtain the interpretation of climatic and oceanographic conditions for each cluster in the past. Temperature variability was available from Damanik et al. (2020) by analyzing changes in groups of foraminifera that live in the Pacific Ocean (Tropic-Subantarctic), according to Barker (1960) in Boltovskoy and Wright (1976). Modern Analogue Technique (MAT) is also done for the sea surface temperature variability based on foraminifera distribution using open software ANALOG (Schweitzer, 1998). In this case, SST in August was chosen to represent the temperature during the southeast monsoon (Austral winter/Boreal summer), while SST February represents

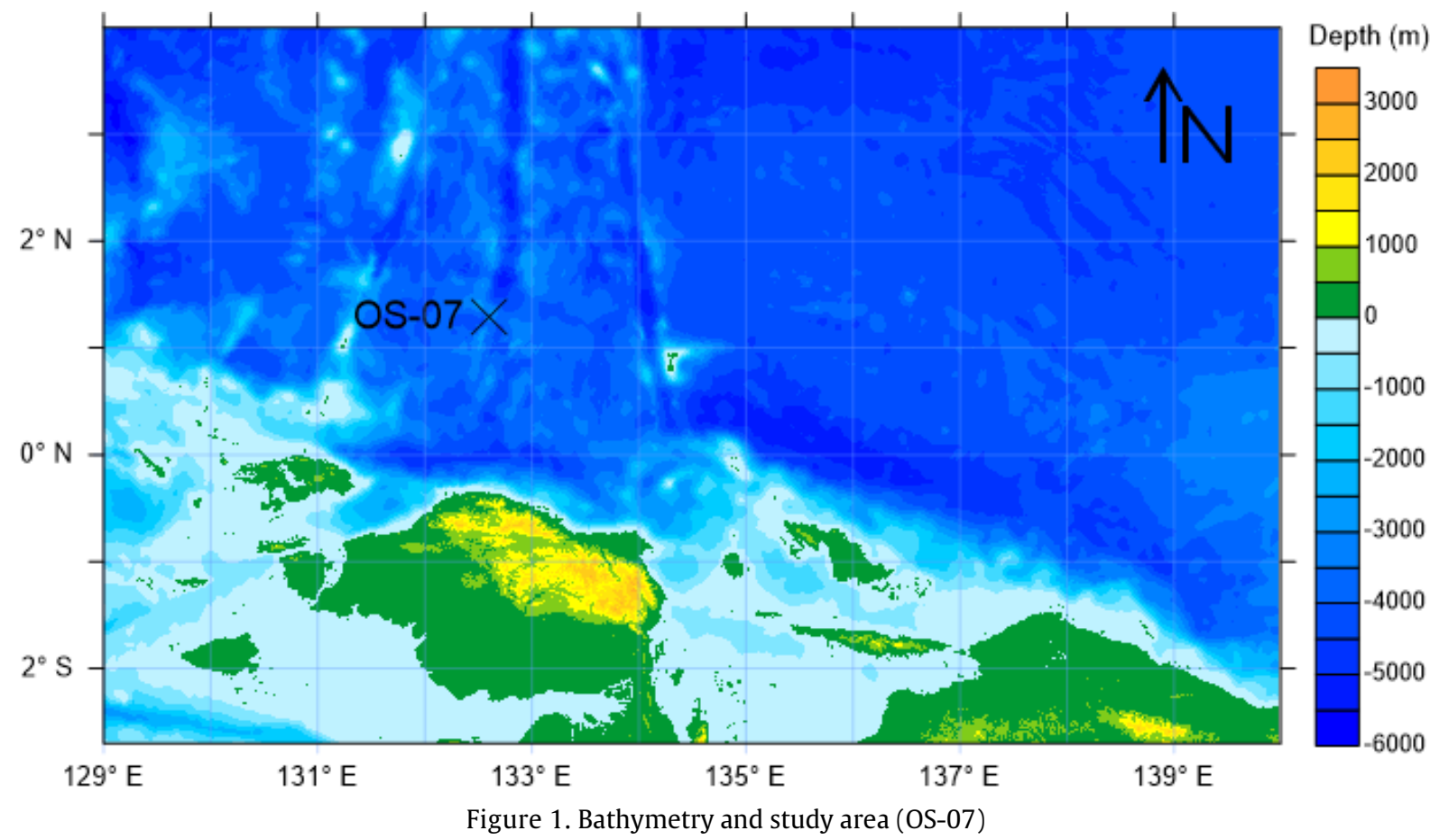


the temperature during northwest monsoon (Austral summer/winter Boreal) (Ardi, 2018; Damanik et al., 2020). Thermocline depth variability based on thermocline dweller taxa abundance ratio (Pulleniatina obliqueoloculata, Neogloboquadrina dutertrei, and Globigerina bulloides) with mixed layer dweller (Group Globigerinoides like G. trilobus, G. ruber, G. sacculiferus, G. conglobatus; Li et al., 2005; Sato et al., 2008; Gustiantini, 2018). Oxygen content derived from the abundance of low-oxygen taxa such as Bolivina, Globobullimina, Bullimina, Uvigerina (Maryunani, 2009). Bottom currents, derived from the abundance of groups Cibicides spp. that tend to live in epifaunal, showing the current intensification of the seabed (Murray, 1991 in Maryunani, 2009). Paleoproductivity is derived from the abundance of Pulleniatina group (Maryunani, 2009; Baohua et al., 1997)).

\section{Results}

\subsection{Geochronology}

Geochronology data for core OS-07 (Table 1) is used to determine the average sedimentation rate, with the assumption linear sedimentation rate (ignoring factors such as sediment compaction, density of grain, viscosity of the fluid, etc.) and top of sediment represent recent conditions.

Radiocarbon dating shows a significant difference in sedimentation rates between depths of $0-126 \mathrm{~cm}$ and $126-246 \mathrm{~cm}$. This difference is the basis of foraminifera analysis resolution. Sedimentation rate is higher on Late Pleistocene (before 16,057 BP), or at depth of $126-246 \mathrm{~cm}$, $0.03495 \mathrm{~cm} /$ year or $34.95 \mathrm{~cm} / 1000$ years, while on Late Pleistocene-Holocene (0-16,057 BP), or at depth of 0-126 $\mathrm{cm}$, have a slower sedimentation rate $0.00785 \mathrm{~cm} /$ year or $7.85 \mathrm{~cm} / 1000$ years.

\subsection{Foraminifera Abundance}

There are 16 samples that cannot reach 300 individuals per $10 \mathrm{~g}$ as the representative (Dennison and Hay, 1967) as the reason the normalized foraminifera abundance results presented as individual counts per $10 \mathrm{~g}$ of sediment. The average foraminifera abundance is 392 , with the lowest abundance is 22 at a depth of $48 \mathrm{~cm}$. The highest abundance is 2,158 individuals at a depth of $80 \mathrm{~cm}$. Foraminifera abundance significantly increases in depth of $72-84 \mathrm{~cm}$ (average: 1,436), while the abundance of foraminifera decrease in depth of $160-168 \mathrm{~cm}, 44-48 \mathrm{~cm}$, $8 \mathrm{~cm}$, and $0 \mathrm{~cm}(<50)$. In general, foraminifera abundance is higher in the younger sediment $(<120 \mathrm{~cm})$.

Benthonic foraminifera abundance is low compared with planktonic foraminifera. The average benthonic foraminifera abundance is only 20 , while planktonic foraminifera abundance is 372 . The highest planktonic foraminifera abundance is 2094, while benthonic foraminifera highest abundance is only 64. The lowest planktonic foraminifera abundance is 15 , and benthonic foraminifera abundance is 2 (Figure 2).

Planktonic foraminifera species that is always present in the sample is Pulleniatina obliqueloculata, with average abundance is 110 . The other abundant species include are Neogloboquadrina dutertrei (62), Globorotalia menardii (40), Globigerinoides ruber(32), Globigerinoides trilobus (17), and Neogloboquadrina spp. (15), while other species like Beela digitata, Candeina nitida, Globigerina bulloides, Globigerinella calida, Globigerinita aglutinata, Globigerinoides conglobatus, Globorotalia scitula, Globorotalia tumida, Globorotalia ungulates, Hastigerina aequilateralis, Hastigerina pelagica, Hastigerina siphonifera, Neogloboquadrina accostaensis, and Orbulina universa has an average abundance of $<10$ (Figure 2).

The abundant benthonic foraminifera species are Melonis pompilideus, Pullenia bulloides, Oolina sp., Planulina bradyii, Oridorsalis umbonatus, Cibicides subhaidingerii, Eggrela bradyii, Planulina wuelestroffi, and Quinqueloculina spp., Which shows the deep-sea environment (Barker, 1960) (Figure 3).

\subsection{Biozonation and IndVal}

Biozonation was done based on the dendrogram with the total sum of square value is 200 . This division can be obtained in two large zones of whole core samples. To obtain more detailed information, the dendrogram cut at the total sum of square value is 70, resulting in 6 clusters, with one cluster on the Pleistocene and 5 clusters in Holocene. Every cluster was then divided, resulting in 17 subclusters in total.

IndVal was calculated to determine the indicator species for every cluster, which can reflect how important the taxa are in representing the ecological conditions (Table 2). The IndVal is dominated by Pulleniatina obliqueloculate except for the clusters $1 \mathrm{~A}, 1 \mathrm{~B}, 1 \mathrm{H}$, and $1 \mathrm{I}$ by Globigerinoides spp.

Each cluster was interpreted by the foraminifera assemblages/species that reflect the specific ecological parameters: foraminifera zonation reflecting temperature, SST results from MAT analysis, and IndVal (Figure 4). Sea surface temperature data (based on foraminifera zonation and MAT analysis) and thermocline depth data in the research area are available from Damanik (2019). Based on the biozonation results, the paleoecology conditions of each cluster can be explained as follows:

Cluster 1A-1C, dominated by Globigerinoides ruber, low SST value, diverse group of foraminifera (not dominated by tropical foraminifera), fluctuating and relatively shallow thermocline depth, low productivity showed by the low Pulleniatina spp. and foraminifera abundance, relative low currents are shown by Cibicides group, and high oxygen content showed by low Bullimina and Uvigerina.

Table 1. Calibrated ages used to determine age model for core OS-07

\begin{tabular}{lll}
\hline Interval Depth $(\mathrm{cm})$ & Species & ${ }^{14}$ C calibrated age (Before Present / BP) \\
\hline $125-126$ & $\begin{array}{l}\text { Neogloboquadrina spp. } \\
\text { Pulleniatina spp. }\end{array}$ & $16057+/-40$ \\
$245-246$ & Globorotalia spp. & $19490+/-60$ \\
\hline
\end{tabular}




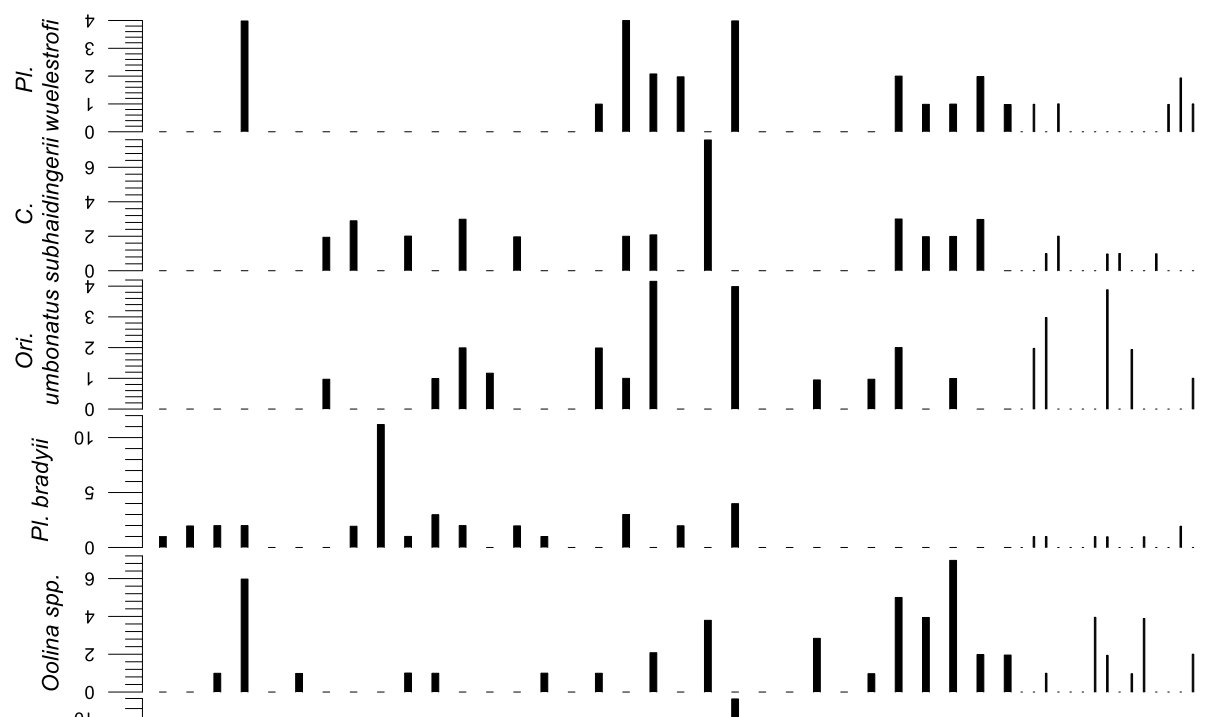

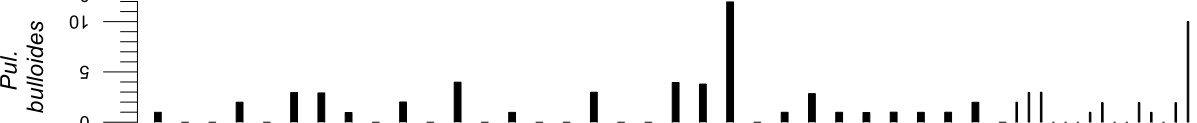

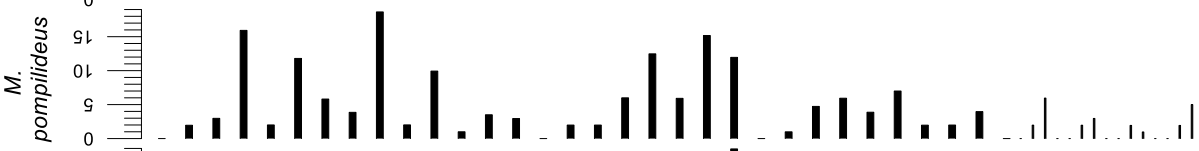

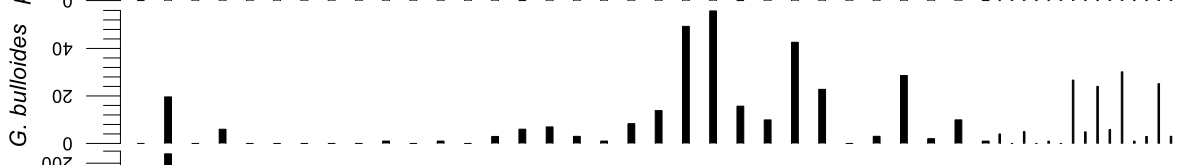

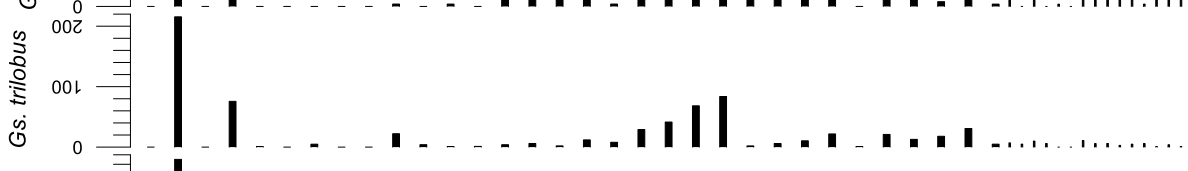

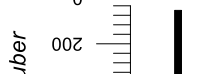

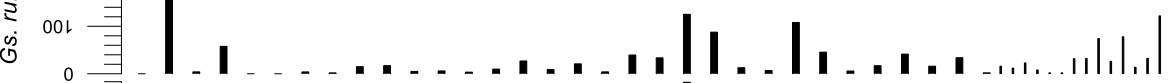

: 002

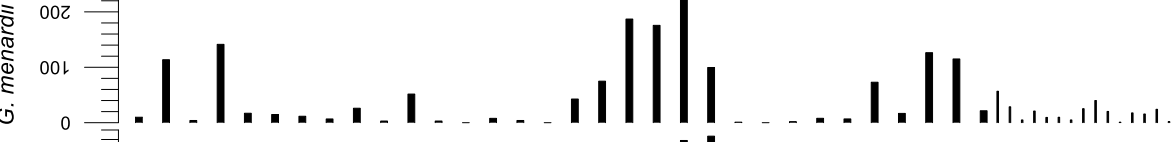

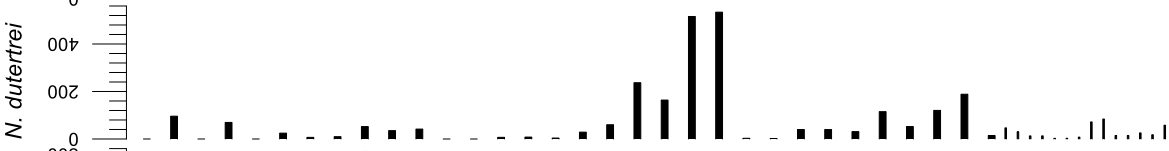

2008

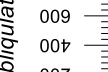

을 002

2. $\begin{aligned} 0 \\ 09\end{aligned}$

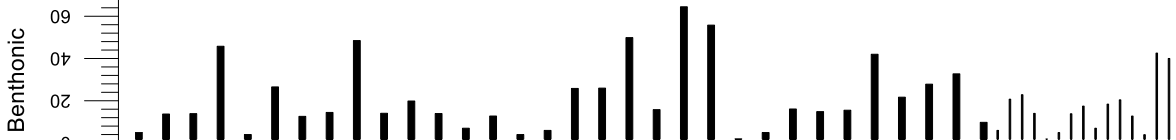
${ }_{0002} \equiv$

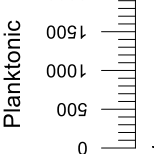

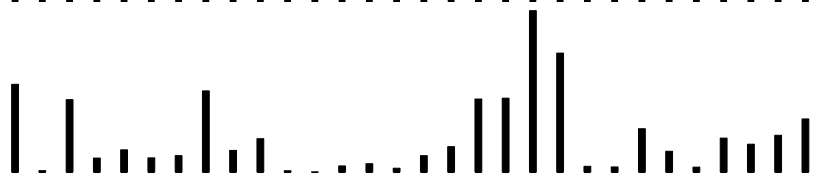

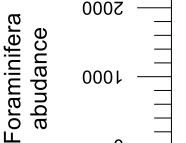

|

| | I | | | |

I | |

. . I I 1 


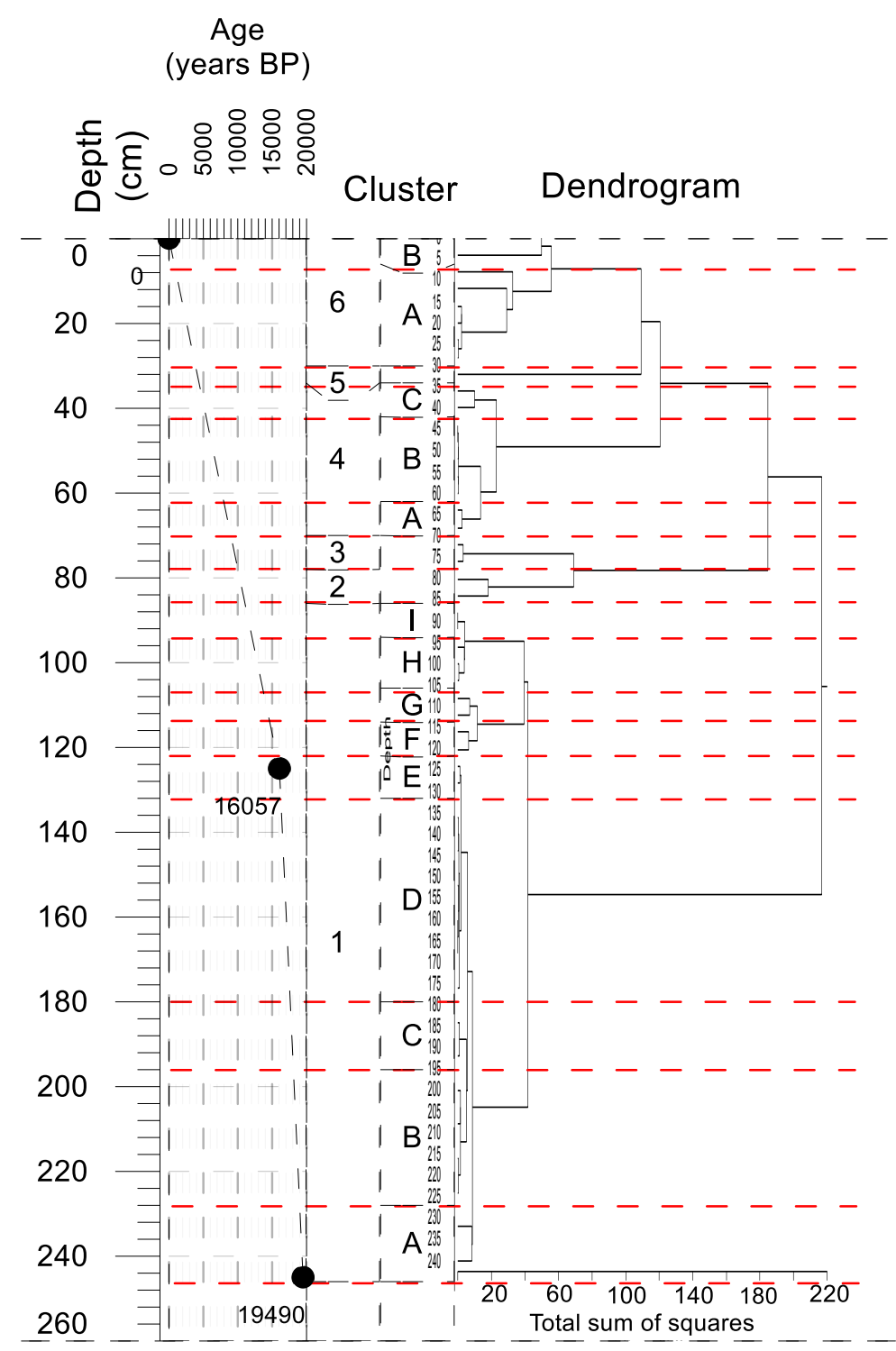

Figure 3. Depth, age model, and dendrogram and cluster division

Cluster 1D-1G dominated by Pulleniatina obliqueloculata, Globorotalia menardii, and Neogloboquadrina dutertrei as the thermocline dweller indicating shallowing thermocline layer. Sea surface temperature relatively increases. This is indicated by increasing foraminifera abundance living at warmer temperatures/tropic foraminifera. The high abundance of Cibicides group at the end of this cluster is indicating a high current. This is in line with increased productivity at the end of the cluster shows by Pulleniatina spp.

Cluster $1 \mathrm{H}-1 \mathrm{I}$ dominated by Globigerinoides ruber, Globigerinoides spp. This indicates a deeping thermocline condition. Sea surface temperature decreases at the end of each cluster $1 \mathrm{H}$ and $1 \mathrm{I}$ cluster that following by increasing of foraminifera group living in cooler temperatures. Low oxygen foraminifera assemblage (Bullimina and Uvigerina) abundance is decreasing, indicating a high level of oxygen content, while Cibicides as the current indicator foraminifera is not present, indicating decreasing current.

Cluster 2-3 dominated by Pulleniatina obliqueloculata, Globorotalia menardii, Neogloboquadrina dutertrei. This indicates shallowing thermocline conditions and increasing productivity agree with Pulleniatina spp. as the IndVal. Sea surface temperature shows an increasing trend shown by the increase of tropic zone foraminifera group assemblages. Low oxygen foraminifera assemblage indicates the high oxygen content, while the current indicator foraminifera is also high, which indicates a current increase.

Cluster $4 \mathrm{~A}-4 \mathrm{~B}$ is still dominated by Pulleniatina obliqueloculata. However, at the beginning of this cluster is indicated with increasing of Globigerinoides ruber. This indicates deep thermocline conditions and very low productivity in cluster 4B. Sea surface temperature is high but shows a downward trend at the beginning of cluster 4B.

Cluster 4C-6A dominated by Pulleniatina obliqueloculata, Neogloboquadrina dutertrei. This indicates the shallowing thermocline condition has started again, and productivity has begun to rise again. The maximum abundance of Pulleniatina obliqueloculata at cluster 5 (820 individuals). 
Table 2. IndVal for every subcluster

\begin{tabular}{|c|c|}
\hline Cluster & Taxa Identifier, IndVal (average abundance) \\
\hline $6 B$ & $\begin{array}{l}\text { Pulleniatina obliqueloculata: } 12,35 \text { (67), } \\
\text { Globorotalia menardii: } 11,36(61), \\
\text { Globigerinoides trilobus: } 19,83(108), \\
\text { Globigerinoides ruber: } 24,88(135)\end{array}$ \\
\hline $6 \mathrm{~A}$ & Pulleniatina obliqueloculata: 74,25 (180) \\
\hline 5 & Pulleniatina obliqueloculata: 75,08 (820) \\
\hline $4 \mathrm{C}$ & $\begin{array}{l}\text { Pulleniatina obliqueloculata: } 57,73(209), \\
\text { Neogloboquadrina dutertrei: } 10,60(39)\end{array}$ \\
\hline $4 \mathrm{~B}$ & $\begin{array}{l}\text { Pulleniatina obliqueloculata: } 17,40(10), \\
\text { Globigerinoides ruber: } 18,79(11)\end{array}$ \\
\hline $4 \mathrm{~A}$ & $\begin{array}{l}\text { Pulleniatina obliqueloculata: } 34,79 \text { (100), } \\
\text { Globorotalia menardii: } 20,52 \text { (59), } \\
\text { Neogloboquadrina dutertrei: } 15,48 \text { ( } 44)\end{array}$ \\
\hline 3 & $\begin{array}{l}\text { Pulleniatina obliqueloculata: } 34,09 \text { (327), } \\
\text { Globorotalia menardii: 18,91 (181), } \\
\text { Neogloboquadrina dutertrei: } 20,89 \text { (200) }\end{array}$ \\
\hline 2 & Pulleniatina obliqueloculata: 24,965(432) \\
\hline $1 \mathrm{I}$ & $\begin{array}{l}\text { Globigerinoides spp.: } 21,73(12) \\
\text { Globigerinoides ruber: } 17,3(10), \\
\text { Globigerina bulloides (pink): 13,04 (8) }\end{array}$ \\
\hline $1 \mathrm{H}$ & $\begin{array}{l}\text { Globigerinoides ruber: } 21,09 \text { (53), } \\
\text { Neogloboquadrina dutertrei: } 14,62 \text { (37) }\end{array}$ \\
\hline $1 G$ & $\begin{array}{l}\text { Pulleniatina obliqueloculata: 24,2 (93), } \\
\text { Neogloboquadrina dutertrei: 21,88 (83) }\end{array}$ \\
\hline $1 \mathrm{~F}$ & $\begin{array}{l}\text { Pulleniatina obliqueloculata: } 28,78 \text { (169), } \\
\text { Globorotalia menardii: } 20,58 \text { (121), } \\
\text { Neogloboquadrina dutertrei: } 26,33154),\end{array}$ \\
\hline $1 \mathrm{E}$ & $\begin{array}{l}\text { Pulleniatina obliqueloculata: } 19,86 \text { (35), } \\
\text { Globorotalia menardii: } 22,43(39), \\
\text { Neogloboquadrina dutertrei: } 17,61 \text { (31), }\end{array}$ \\
\hline 1D & $\begin{array}{l}\text { Pulleniatina obliqueloculata: } 11,41 \text { (11), } \\
\text { Globorotalia menardii: 13,16 (13), } \\
\text { Globigerinoides ruber: 13,04 (13), } \\
\text { Neogloboquadrina dutertrei: } 11,71 \text { (12), }\end{array}$ \\
\hline $1 C$ & $\begin{array}{l}\text { Pulleniatina obliqueloculata: } 15,47 \text { (52), } \\
\text { Globigerinoides ruber: } 15,60 \text { (53), } \\
\text { Neogloboquadrina dutertrei: 22,93 (18), }\end{array}$ \\
\hline 1B & $\begin{array}{l}\text { Globigerinoides ruber: } 23,61 \text { (38), } \\
\text { Neogloboquadrina dutertrei: 11,37 (18) }\end{array}$ \\
\hline $1 \mathrm{~A}$ & $\begin{array}{l}\text { Globigerinoides ruber: } 26,57 \text { (63), } \\
\text { Neogloboquadrina dutertrei: } 12,99 \text { (31), }\end{array}$ \\
\hline
\end{tabular}

Cluster 6B is dominated by Pulleniatina obliqueloculata, Globorotalia menardii, Globigerinoides trilobus, Globigerinoides ruber. This indicates deepening thermocline conditions. Sea surface temperature in this cluster shows a downward trend. The absence of low oxygen foraminifera assemblages and current foraminifera indicator indicates a relatively weaker current than the previous cluster.

\section{Discussions}

The foraminifera abundance shows high variability especially during the cooler sea surface temperature. The most abundance foraminifera species is Pulleniatina obliqueoloculata that is agree with the tropic condition in this research area (Boltovskoy and Wright, 1976). Pulleniatina obliqueoloculata can shows the productivity changes as the abundance showing same trend with the foraminifera abundance. As Pulleniatina obliqueloculata is abundant and living in the thermocline layer, the percentage of the thermocline dweller mostly has the same trend with the foraminifera abundance.

As the most abundant and IndVal for mostly all the clusters, Pulleniatina spp. abundance variability in line with the first biozonation showing the broader different environment and different ecological conditions between glacial (Pleistocene; Cluster 1) and interglacial (the Holocene; Cluster 2-6). Pleistocene with the cooler sea surface temperature, relative weak current, and lower productivity. Holocene shows warmer sea surface temperature, a relatively stronger current, and higher productivity.

On the Pleistocene, the sediment input and thermocline depth are affected by the high latitude climate event that is also identified by the foraminifera distribution, which is lower productivity and cooler temperature. This cluster is interpreted as glacial conditions or following the conditions of the Last Glacial Maximum (Cluster 1A-1C; 19-17 kyr BP). The boundary between Pleistocene and Holocene showed by the decreasing productivity in the cluster $1 \mathrm{H}$ and $1 \mathrm{I}$ as the transition. Pulleniatina spp. changed by mixed layer dweller, Globigerinoides spp. is showing cooler sea surface temperature, deeping thermocline layer, and lower productivity that also recorded in Okinawa Through (Baohua et al., 1997). Subsequently, the high productivity showed by high Pulleniatina indicating this period as the Younger Dryas climatic period ( 11-9 kyr BP), and is interpreted in association with the last cooling events in the Pleistocene and also as the Pleistocene-Holocene boundary (Gustiantini et al., 2015). This is indicated by the domination of Pulleniatina as the IndVal that was also recorded in the Halmahera Sea (Pratiwi et al., 2020). Pulleniatina has known as the indicator of high nutrients that occurred on the Younger Dryas event (Baohua et al., 1997).

The Indonesian Through flow is higher on the Holocene as shown by the increase of Cibicides. The cause of this higher condition is probably affected by the ENSO and showed by the smooth fluctuation of the thermocline that is showing the changes in thermocline depth as one of ENSO effects (NOAA, 2020). There is a decreasing and increasing sea surface temperature on the Holocene, which is interpreted as $8,2 \mathrm{~K}$ events and Holocene Thermal Maximum. It is also indicated by the increase of foraminifera living in lower temperatures. The high abundance of low oxygen foraminifera assemblage in cluster $4 \mathrm{~A}$ indicates the oxygen content is low, while the current indicator foraminifera abundance is high shows an increasing current.

This warmer sea surface temperature is also in line with the peak of the shallowing thermocline and very high productivity. This period ( $4 \mathrm{kyr}$ BP) is interpreted as associated with Mid-Holocene Transition, which is the hottest period during the Holocene, which also occurred in the Halmahera Sea (Gustiantini et al., 2015). In general, in this cluster, sea surface temperatures are high, indicated by the dominance of tropical foraminifera. The absence of low oxygen foraminifera assemblage indicates high oxygen content, and high currents, which is indicated by the high abundance of current indicator foraminifera interpreted to bring the nutrient relating to high productivity in this time. 


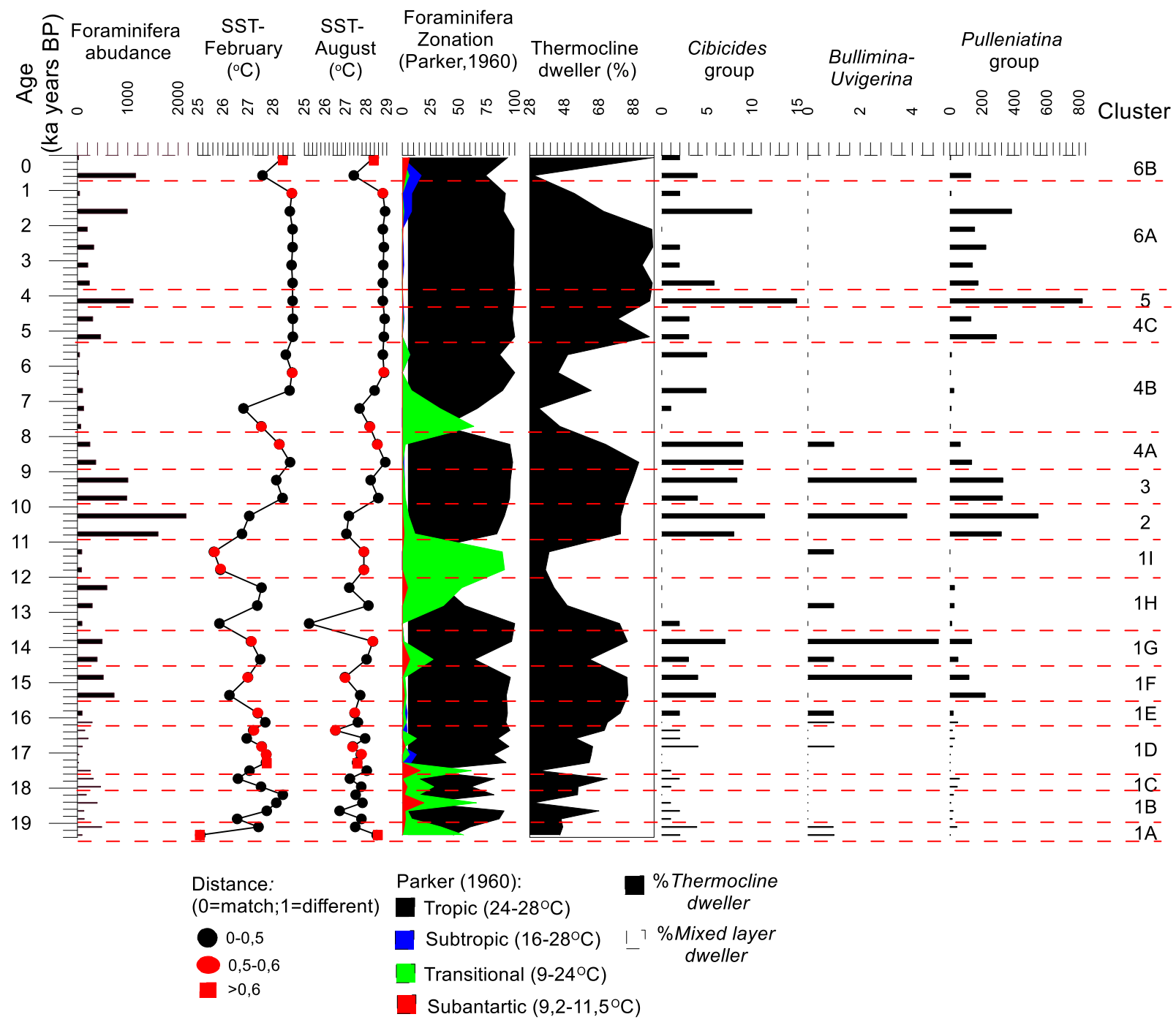

Figure 4. Sea Surface Temperature, identifier foraminifera for ecology, and cluster division

\section{Conclusion}

Global climate change affects the distribution of foraminifera in North Papua Waters, Pacific Ocean. The cluster division shows a significant difference between foraminifera distribution in the Late Pleistocene/Glacial and Holocene/Interglacial. Detail distribution of foraminifera in the research area is divided into 17 clusters affected by global climate variability. Biozonation shows climate variability since the Late Pleistocene, record Pleistocene-Holocene boundary based on the significant variability of foraminifera distribution and records some of the global climate events such as Last Glacial Maximum ( 19-17 kyr), Younger Dryas ( 11-9 kyr), $8,2 \mathrm{~K}$ event, and Mid-Holocene Transition ( $4 \mathrm{kyr})$.

\section{Acknowledgment}

The authors thank Research Center for Oceanography, Indonesian Institute of Sciences, so this research can be conducted in Nusa Manggala Expedition 2018. The authors also thank the Head of Research Center for Geotechnology, Indonesian Institute of Sciences for the facilities granted to conduct laboratory analysis.

\section{References}

Adisaputra, M.K., Hendrizan, M., Kholiq, A., 2010. Katalog Foraminifera Perairan Indonesia. Pusat Penelitian dan Pengembangan Geologi Kelautan, Bandung.

Ardi, R.D.W., 2018. Rekonstruksi paleoklimatologi dan paleooseanografi sejak Pleistosen Akhir berdasarkan kumpulan foraminifera di lepas pantai barat daya Pulau Sumba, Nusa Tenggara Timur. Tesis Magister, Insitut Teknologi Bandung.

Ardi, R.D.W., Maryunani, K.A., Yulianto, E., Putra, P.S., Nugroho, S.H., 2019. Biostratigrafi dan analisis perubahan kedalaman termoklin di Lepas Pantai Barat Daya Sumba sejak Pleistosen akhir berdasarkan kumpulan foaminifera planktonik. Bull. Geol. 3. https://doi.org/10.5614/bull.geol.2019.3.2.3

Baohua, L., Zhimin, J., Pinxian, W., 1997. Pulleniatina obliquiloculata as a paleoceanographic indivation in the southern Okinawa Trough during the last 20,000 years. Science (80-. ). 32, 59-69.

Barker, R.W., 1960. Taxonomic Notes on the Species Figures by H.B. Brady in his report on the foraminifera dredged by H.M.S. Challenger during years 1873-1876. Soc. Econ. Paleontol. Mineral. Spec. Publ. 9, 24-238.

Bé, A.W.H., Hutson, W.H., 1977. Ecology of Planktonic Foraminifera and Biogeographic Patterns of Life and Fossil Assemblages in the Indian Ocean. Micropaleontology 23, 369. https://doi.org/10.2307/1485406 
Blow, W.H., 1969. Late Middle Eocene to Recent Planktonic Foraminiferal Biostratigraphy. Geneva.

Bolli, H.M., Saunders, J.B., Perch-Nielsen, K., 1985. Plankton Stratigraphy.

Boltovskoy, E., Wright, R., 1976. Recent Foraminifera.

Damanik, A., 2019. Analisis Multiproksi Kondisi Paleoklimat dan Paleoseanografi pada Pleistosen Akhir-Holosen di Perairan Utara Papua, Samudra Pasifik. Tesis Magister, Insitut Teknologi Bandung.

Damanik, A., Maryunani, K.A., Nugroho, S.H., Putra, P.S., 2020. Rekonstruksi Perubahan Suhu Permukaan Laut Berdasarkan Kumpulan Foraminifera di Perairan Utara Papua, Samudra Pasifik. Bull. Geol. 4, 496-504. https://doi.org/10.5614/bull.geol.2020.4.1.4

Dennison, J.M., Hay, W.W., 1967. Estimating the needed sampling area for subaquatic ecologic studies. J. Paleontol. 41, 706-708.

Dufrene, M., Legendre, P., 1997. Species Assemblages and Indicator Species: The Need for a Flexible Asymmetrical Approach. Ecol. Soc. Am. 67, 345-366.

Fraile, I., Schulz, M., Mulitza, S., Kucera, M., 2008. Predicting the global distribution of planktonic foraminifera using a dynamic ecosystem model. Biogeosciences 5, 891-911. https://doi.org/10.5194/bg-5-891-2008

Gordon, A.L., 2005. Oceanography of the Indonesian Seas and their throughflow. Oceanography 18, 14-27. https://doi.org/10.5670/oceanog.2005.18

Gustiantini, L., 2018. Paleoclimate Reconstructions by Multiproxy Approaches in the Halmahera Sea Since the Late PleistoceneHolocene. Disertasi Doktoral, Institut Teknologi Bandung.

Gustiantini, L., Maryunani, K.A., Zuraida, R., Kissel, C., Bassinot, F., Zaim, Y., 2015. Distribusi Foraminifera di Laut Halmahera dari Glasial Akhir sampai Resen. J. Geol. Kelaut. 13, 25-36.

Hasanudin, M., 1998. Arus Lintas Indonesia (Arlindo). Oseana XXIII, 1-9.

Ilahude, A.G., Nontji, A., 1999. Oseanografi Indonesia dan Perubahan Iklim Global (El Nino dan La Nina). Puslitbang Oseanologi, LIPI 1-13.

Kirci-Elmas, E., 2013. Benthic Foraminiferal Distribution (Living and Dead) From a Permanently Stratified Marginal Sea (Marmara Sea, Turkey). J. Foraminifer. Res. 43, 340-360.

Li, B., Jian, Z., Li, Q., Tian, J., Wang, P., 2005. Paleoceanography of the South China Sea since the middle Miocene: evidence from planktonic foraminifera. Mar. Micropaleontol. 54, 49-62. https://doi.org/10.1016/j.marmicro.2004.09.003

Lutze, G.F., Coulbourn, W.T., 1984. Recent benthic foraminifera from the continental margin of northwest Africa: Community structure and distribution. Mar. Micropaleontol. 8, 361-401. https://doi.org/10.1016/0377-8398(84)90002-1

Maryunani, K.A., 2009. Microfossil approached based on Cendrawasih Bay data, to interpreting and reconstructing Equatorial Western Pacific paleoclimate since Last Glacial (Late Pleistocene). Disertasi Doktoral, Institut Teknologi Bandung.
Naidu, P.D., 1993. Distribution patterns of Recent planktonic foraminifera in surface sediments of the western continental margin of India. Mar. Geol. 110, 403-418. https://doi.org/10.1016/0025-3227(93)90097-F

NOAA, 2020. What is El Niño? https://www.pmel.noaa.gov/elnino/what-is-el-nino (diakses 5.10.20).

Nugroho, S.H., Damanik, A., 2018. On Board Report - Dinamika Iklim Masa Lalu (Paleoklimatologi) - Ekspedisi Nusa Manggala 2018.

Pratiwi, F.R., Hadisusanto, S., Gustiantini, L., Nurdin, N., 2020. Keterkaitan Perubahan Iklim pada Glasial Akhir-Holosen terhadap Tingkat Keanekaragaman Foraminifera di Laut Halmahera. J. Geol. Kelaut. 18, 1-10.

Ramsey, C.B., 2009. Bayesian analysis of radiocarbon dates. Radiocarbon 51, 337-360. https://doi.org/10.1017/s0033822200033865

Reimer, P.J., Bard, E., Bayliss, A., Beck, J.W., Blackwell, P.G., Bronk, C., Caitlin, R., Hai, E.B., Edwards, R.L., 2013. Intcal13 and marine13 radiocarbon age calibration curves $0-50,000$ years cal bp. Radiocarbon 55, 1869-1887.

Saraswat, R., 2015. Non-destructive foraminiferal paleoclimatic proxies: A brief insight. Proc. Indian Natl. Sci. Acad. 81, 381 395. https://doi.org/10.16943/ptinsa/2015/v81i2/48094

Sato, K., Oda, M., Chiyonobu, S., Kimoto, K., Domitsu, H., Ingle, J.C., 2008. Establishment of the western Pacific warm pool during the Pliocene: Evidence from planktic foraminifera, oxygen isotopes, and $\mathrm{Mg} / \mathrm{Ca}$ ratios. Palaeogeogr. Palaeoclimatol. Palaeoecol. 265, 140-147. https://doi.org/10.1016/j.palaeo.2008.05.003

Sprintall, J., Gordon, A.L., Koch-Larrouy, A., Lee, T., Potemra, J.T., Pujiana, K., Wijffels, S.E., 2014. The Indonesian seas and their role in the coupled ocean-climate system. Nat. Geosci. 7, 487492. https://doi.org/10.1038/ngeo2188

\section{Declarations}

\section{Funding statement}

This research did not receive any specific grant from funding agencies in the public, commercial, or not-for-profit sectors.

\section{Conflict of interest}

The authors declare no known conflict of financial interest or personal relationships that could have appeared to influence the work reported in this paper.

\section{Additional information}

Reprints and permission information is available at https://mri.lipi.go.id

Publisher's Note: Indonesian Institute of Sciences remains neutral with regard to jurisdictional claims in published maps and institutional affiliations. 